\title{
Gamma-ray spectrometry application for mass movements of the Paranaguá Terrane, southern Brazil
}

Jessica D. Weihermann ${ }^{1}$, Francisco J. F. Ferreira ${ }^{2}$, Leonardo F. Cury ${ }^{2}$, Claudinei T. da Silveira ${ }^{3}$. ${ }^{1}$ Programa de PósGraduação em Geologia da Universidade Federal do Paraná, 'Departamento de Geologia da Universidade Federal do Paraná, ${ }^{3}$ Departamento de Geografia da Universidade Federal do Paraná.

\section{Copyright 2016, SBGf - Sociedade Brasileira de Geofísica}

Este texto foi preparado para a apresentação no VII Simpósio Brasileiro de Geofísica, Ouro Preto, 25 a 27 de outubro de 2016. Seu conteúdo foi revisado pelo Comitê Técnico do VII SimBGf, mas não necessariamente representa a opinião da SBGf ou de seus associados. É proibida a reprodução total ou parcial deste material para propósitos comerciais sem prévia autorização da SBGf.

\section{Abstract}

The Paranaguá Terrane, located in the coastal portion of the states of Santa Catarina, Paraná and São Paulo, Southern Brazil, is a crustal segment constituted mainly by an igneous complex, with a variety of granitic rocks inserted in the Serra do Mar mountain ridge. This research aims to evaluate the gamma-ray spectrometry data of granitic suites of the Paranaguá Terrane, in correspondence with the relief and mass movements information available in the literature. In March $11^{\text {th }} 2011$, associated with a high volume of accumulated rain, a set of predominantly translational mudslides occurred, on the slopes of the Serra da Prata ridge. The investigation of the gamma-ray spectrometric responses through the relief and scars were consistent, being related with the high anomalies.

\section{Introduction}

The present work is part of the research developed in the master's thesis of Weihermann (2016). The Paranaguá Terrane, located in the coastal portion of the states of Santa Catarina, Paraná and São Paulo, Southern Brazil (Fig. 1), is marked to the east by the Brazil shoreline, the southwest by gneissic-granulite rocks of the Luis Alves Microplate and the northwest by Curitiba Microplate (Fig. 2). All the occidental contact is tectonic, being represented in its south-southwest portion by the Palmital lineament and in the west-northwest by Alexandra and Serra Negra lineaments. It is characterized by an igneous complex, with a variety of granitic rocks distributed from the northeast of the Santa Catarina State to the southeast of the São Paulo State, represented by Morro Inglês, Rio do Poço and Canavieiras-Estrela Suites (Fig. 2) and the gneiss and gneissic-migmatitic country rocks inserted into São Francisco Complex and the metasedimentary rocks in the Rio das Cobras Sequence (Cury, 2009).

In recent decades, airborne gamma-ray spectrometry has been established as a tool for geophysical-geological mapping to aid both mineral exploration and lithological information. The gamma-ray spectrometric results in areas of granitic rocks are outstanding in total count and $\mathrm{K}$, eU, eTh maps due to significant levels of these elements in igneous rocks (Gunn et al., 1997). The gamma-ray spectrometry method measures the relative abundance or concentration of $\mathrm{K}$, eU and eTh in rocks and weathered materials with up to $30-45 \mathrm{~cm}$ deep, by detecting the gamma radiation emitted by the natural radioactive decay of these elements (Dickson \& Scott, 1997; Gunn et al., 1997; Minty, 1997; Wilford et al., 1997; Wilford, 2002; IAEA, 2003). The main sources of gamma radiation are derived from the disintegration of potassium$40\left({ }^{40} \mathrm{~K}\right)$, bismuth-214 from the uranium-238 $\left({ }^{238} \mathrm{U}\right)$ decay series and thallium-208 from the thorium $232\left({ }^{232} \mathrm{Th}\right)$ decay series. The total radioactivity is obtained by measurement of all gamma rays detected by gamma-ray spectrometer within the energy window set for the radionuclides (Grasty et al., 1985).

Mass movements are defined as the down slope movement of rock and regolith near the Earth's surface mainly due to the force of gravity. They are an important part of the erosional process, as it moves material from higher elevations to lower elevations where transporting agents like streams can then pick up the material and move it to even lower elevations. These processes are occurring continuously on all slopes; some act very slowly, others occur very suddenly, often with disastrous results. Any perceptible down slope movement of rock or regolith is often referred to in general terms as a landslide. The main focus of this work is to establish a relationship between the gamma-ray spectrometric data and mass movements occurred at the study area.

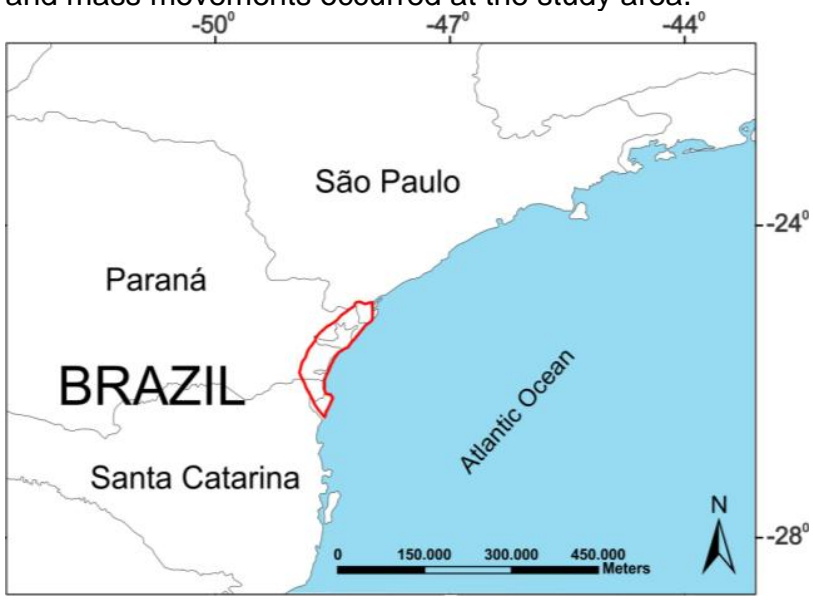

Figure 1 - Location of the Paranaguá Terrane in red.

\section{Methodology}

In the present research, gamma-ray spectrometric data (K, eU, eTh) of the Paranaguá Terrane (Fig. 2) from the Aerogeophysical Paraná-Santa Catarina Project (CPRM, 2011) was processed and interpreted in the Laboratory for Research in Applied Geophysics. After data quality analysis, the data set was interpolated in regular square

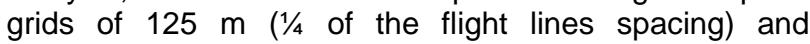


represented in basic (K, eU, eTh) and ternary (RGB) maps. To evaluate the study of mass movements an area was selected, the northern portion of Serra da Prata ridge, previously studied by Silveira et al. $(2013,2014)$ (black square of Fig. 2).

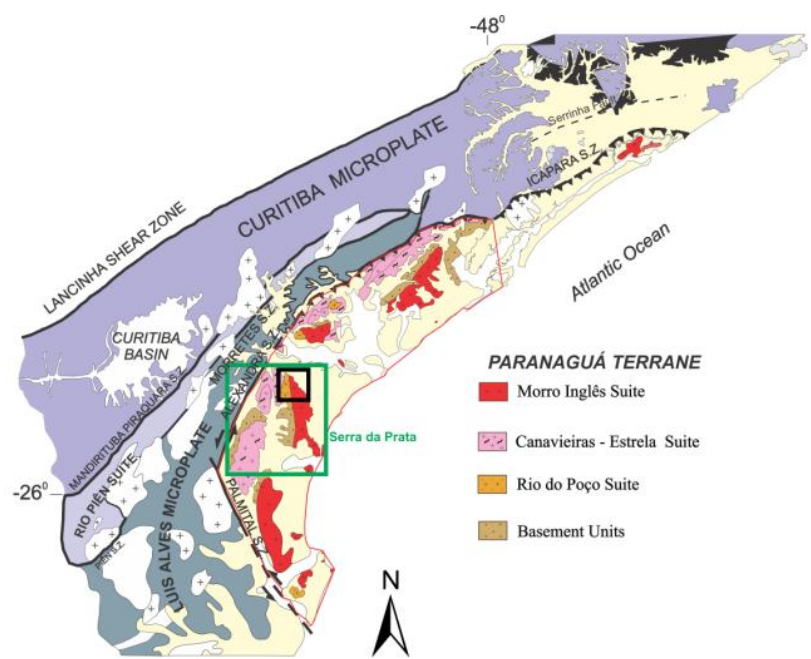

Figure 2 - Geological map of the Paranaguá Terrane in red and the Serra da Prata ridge indicated in green with the northern portion in black.

An integration of geophysical and geological data, with elevation (SRTM - Shuttle Radar Topography Mission, USGS, spatial resolution of $\sim 30 \mathrm{~m}$ ), DEM (digital elevation model, Laboratory for Applied Research in Geomorphology and Geotechnologies, spatial resolution of $\sim 15 \mathrm{~m}$ ) and satellite images, like WorldView-1 (spatial resolution of $\sim 0.6 \mathrm{~m}$ ), was carried out in a GIS environment (Geographic Information System).

The correlation between geophysics and mass movements was made through the study of slope, hypsometric and scar maps compared with basic radiometric maps $(\mathrm{K}$, eTh and $\mathrm{eU})$. The anomalies of $\mathrm{K}$, eTh and eU were defined by the mean +1 standard deviation. Through a detailed analysis of the northern portion of the Serra da Prata (black square of Fig. 2) was possible to relate mass movements with gamma-ray spectrometry, due to an event dated in March $11^{\text {th }} 2011$.

\section{Results and Discussion}

The research area is inserted in the Serra do Mar mountain ridge, which is recognized as an environment of high susceptibility to mass movements (Fiori, 1995; Silveira et al., 2013). These processes are associated with the genesis and evolution of the relief (Almeida \& Carneiro, 1998).

In March $11^{\text {th }} 2011$, associated with a high volume of accumulated rain $(230 \mathrm{~mm}$ in 24 hours, $305 \mathrm{~mm}$ in 48 hours and $382 \mathrm{~mm}$ in 72 hours), contrasting with the daily cumulative rain volume of about $50 \mathrm{~mm}$ and the annual average of $2436 \mathrm{~mm}$, a set of predominantly translational landslides and mudslides occurred, on the slopes of the Serra da Prata ridge. The bulk of material loosened by the landslide was transported through the valleys, remobilizing previous deposits, and was deposited in the coastal plain (Silveira et al., 2014).

The gamma-ray spectrometric results arising from this event were studied in the northern portion of the Serra da Prata ridge (black square in Figure 2), where previously studies on mass movements and risk areas have been developed by Silveira et al. (2013, 2014). The airborne survey data in this area was obtained mainly after the event $(03 / 18 / 2011$ - 08/13/2011) and the gamma-ray spectrometric responses described below are related to the post-event situation. Slope, hypsometric and scar maps were generated (Fig. 3).

The slope is related with the tangent plane to the topography surface, the hypsometry linked with the variation of altitude and the scars were mapped by Silveira et al. (2013) and Silveira et al. (2014). It was possible to verify that $95 \%$ of the slide areas occurred in slopes greater than $25 \%$ (Fig. 3a) and $82 \%$ of the scars mapped were related to altitude higher than $400 \mathrm{~m}$ (Fig. 3 b,c). The highest elevations are supported by differential erosion of more resistant rocks, resulting in slopes/hillsides, which have greater energy and favor mass movement processes (Silveira et al., 2013; Silveira et al., 2014).

a)

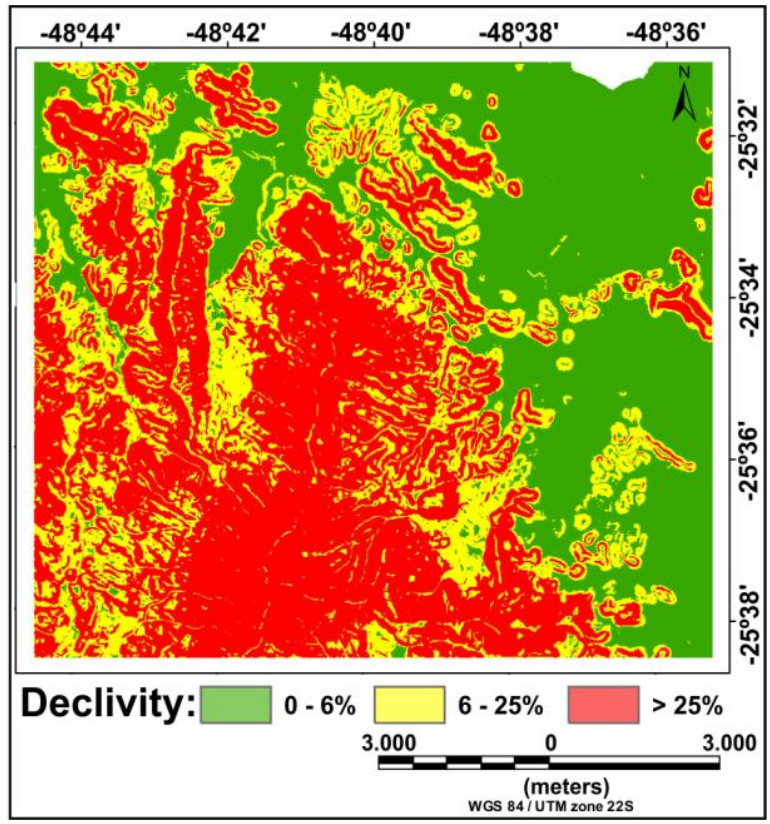


b)

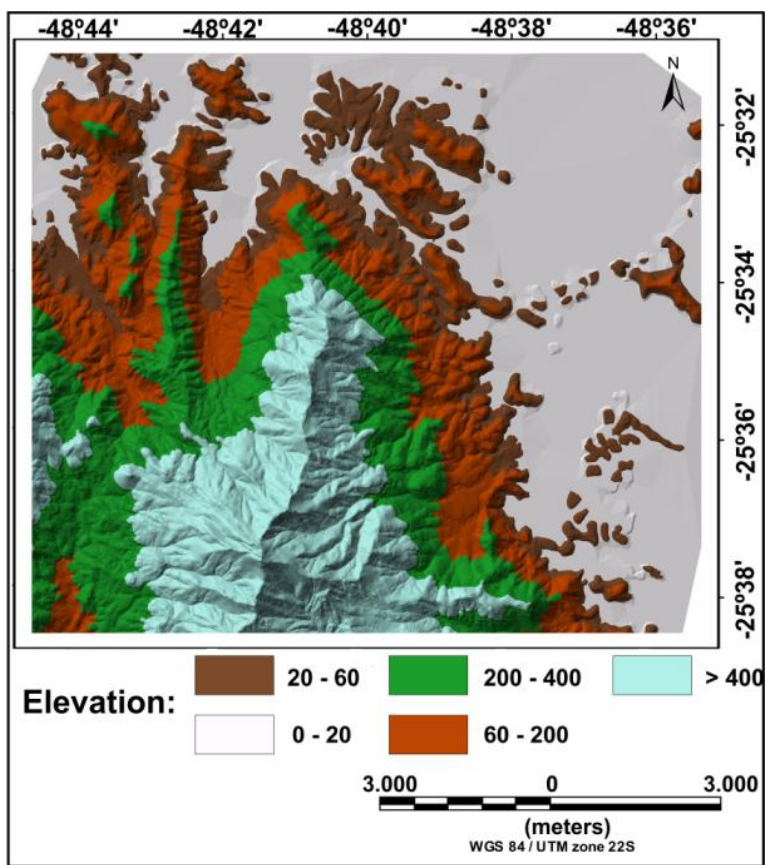

c)

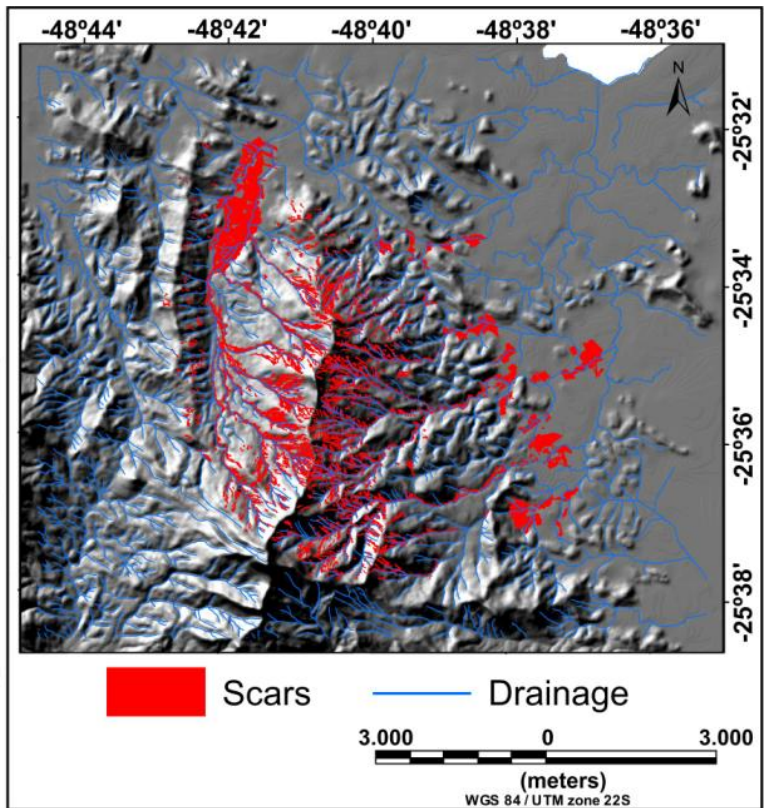

Figure 3 - Maps of the northern portion of the Serra da Prata ridge (black square in Fig. 2): (a) slope, (b) hypsometric, (c) scars.

The gamma-ray spectrometric anomalies of $\mathrm{K}$, eTh and $\mathrm{eU}$ were defined by the mean +1 standard deviation (Fig. 4), which correspond to scars related to mass movements (Fig. 3c), and are conditioned by the drainage system. Figure 4d shows the K (red), eTh (green) and eU (blue) anomalies, which correspond, predominantly, to the scars. The highest values of the three radioelements are linked to altimetric quotes between 200 and $400 \mathrm{~m}$ and > $400 \mathrm{~m}$ (Fig. 4d).
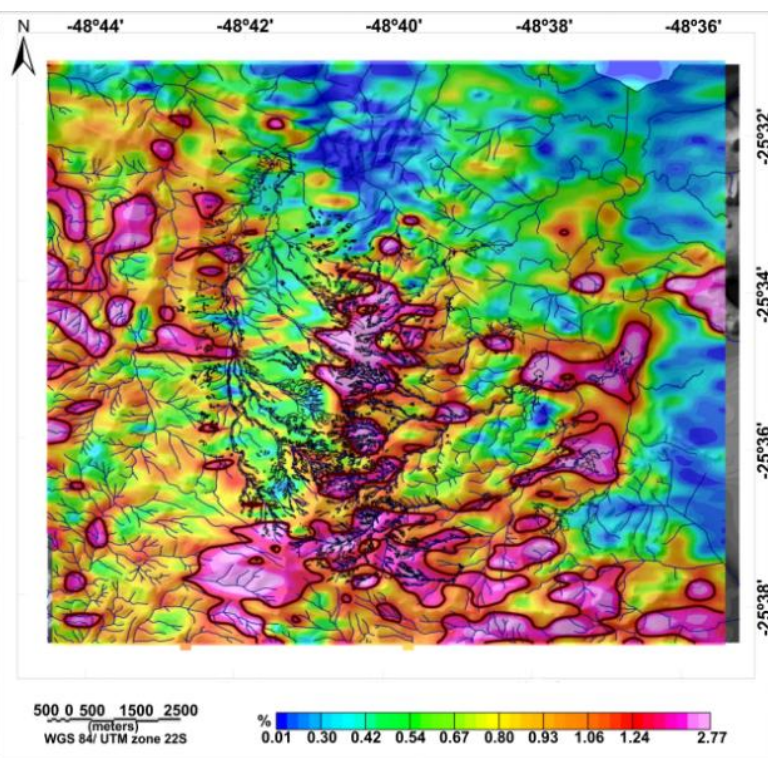

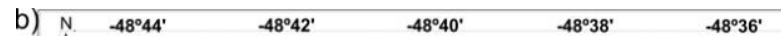

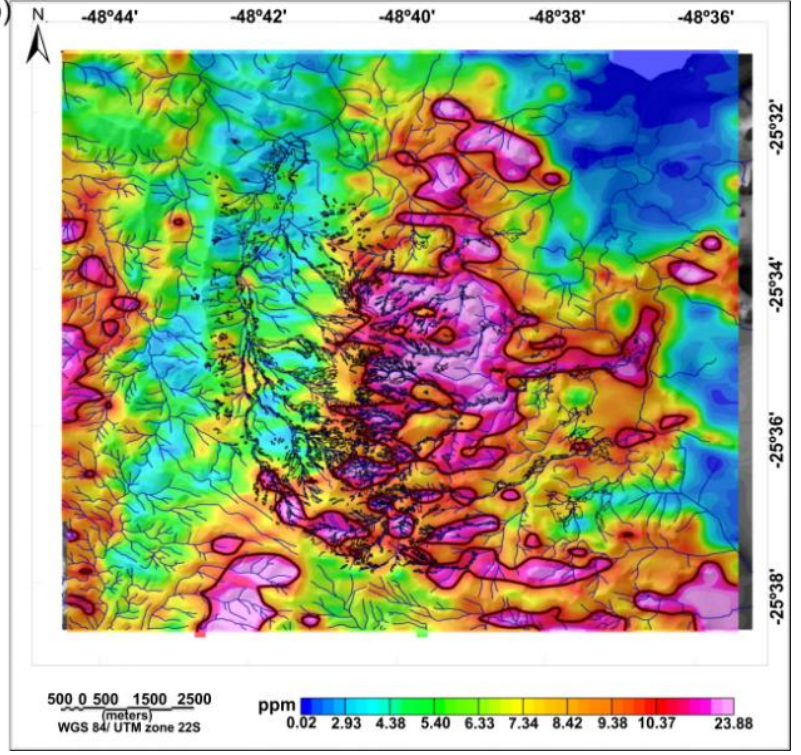




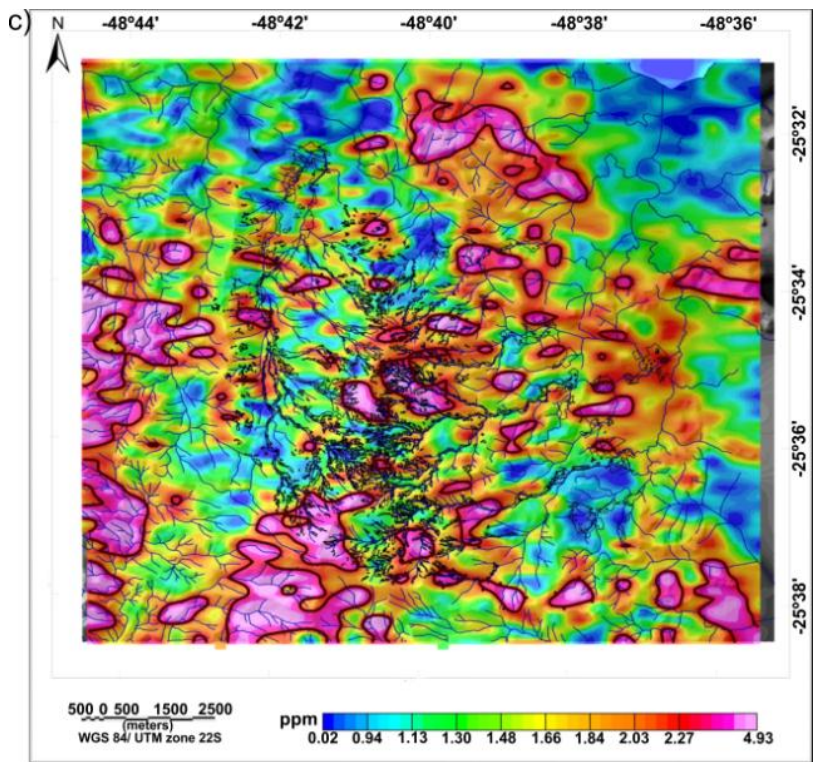

d)

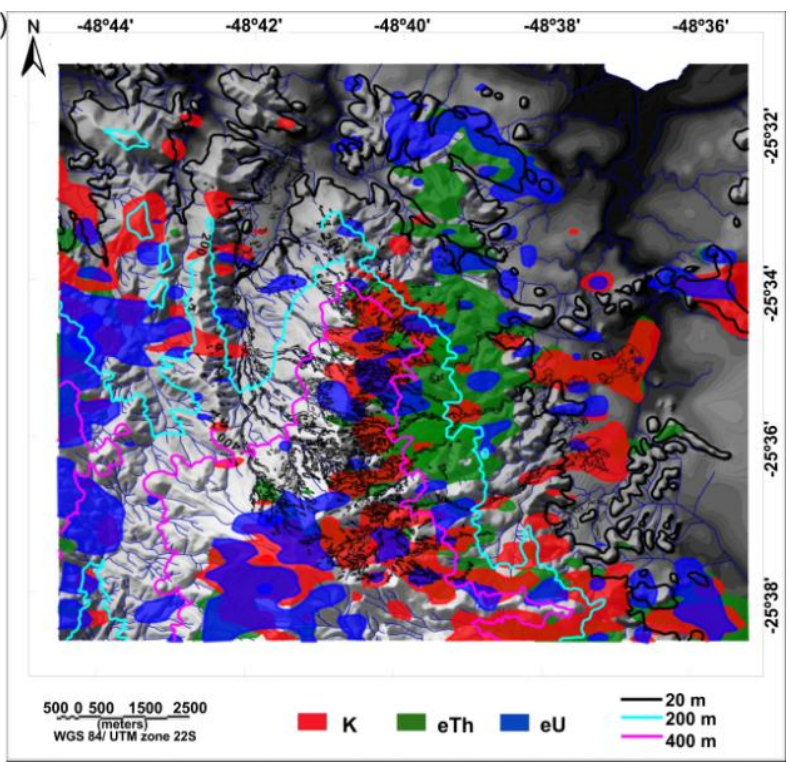

Figure 4 - Maps of gamma-ray spectrometric anomalies showing their spatial relationship with the scars (see Fig. $3 c$ ) on the northern portion of Serra da Prata ridge (black square in Fig. 2). (a) $K$, (b), eTh, (c) eU and (d) $K$, eTh, $\mathrm{eU}$ combination indicating the scars, the drainage network, digital elevation model (DEM) and altimetric quotes.

Considering that thorium is the less geochemically mobile element, the migratory trend of higher altimetric quotes to the lower ones (e.g. Fig. 4b,d), is due to the mass movements. A schematic geological profile of this northern portion of the Serra da Prata ridge (Figs. 5 and 6) summarizes the behavior of $\mathrm{K}$, eTh and eU. The migration of radionuclides to lower elevations may be observed, particularly on the coastal plain, where their concentration should theoretically be low.
In this context, the observed anomalous values are probably due to the characteristic mass movements in the region, controlled by the drainage system and the intense rainfall. In the profile $X-X^{\prime}$ displayed in Figure 6 , based on radiometric, geological and geomorphological characteristics, we relate the Canavieiras-Estrela Suite with intermediate values of radionuclides, the Rio do Poço Suite with lower grades and Morro Inglês Suite with the highest concentrations. The high concentrations of the Morro Inglês Suite are not only related to petrography (potassium feldspar megacrystals), but also to the fresh rock exposure (considerably number of scars) resulted from the high-energy mass movements (slopes greater than $25 \%$ ). On the other hand, the high values in the coastal plain can be explained by the remobilization of these elements with their transport related to mass movements.

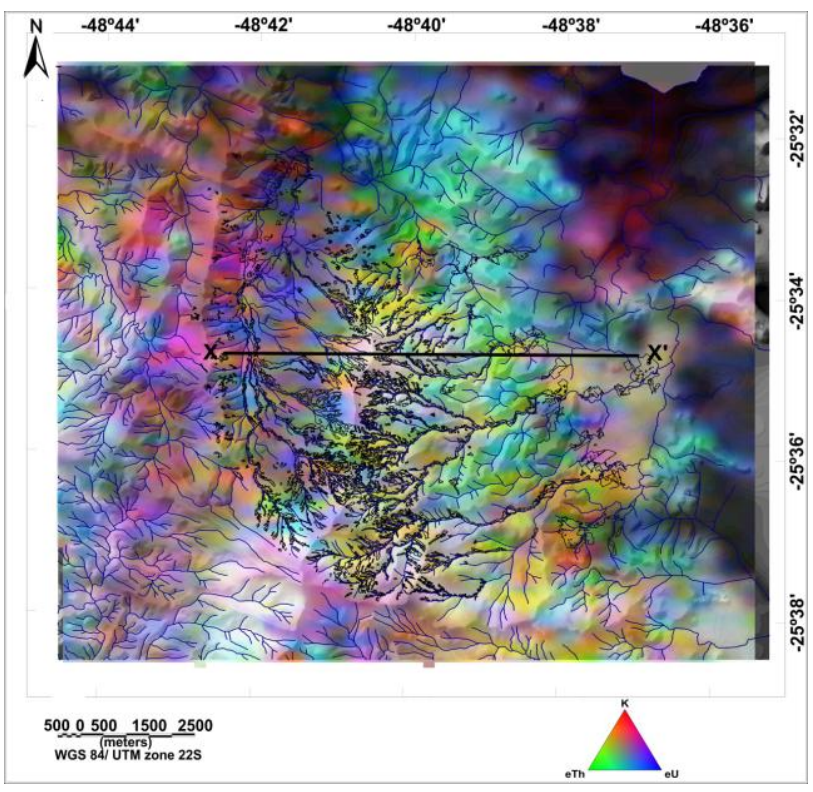

Figure 5 - Ternary map of the northern portion of the Serra da Prata ridge (black square in Fig. 2) indicating the location of the profile $X-X^{\prime}$ in Figure 6.

Finally, Figure 7 displays this mobility in 3D models, where the scars are located mainly along the interfluves of the watershed and the radionuclides depleted are located along the rivers, with a deposit of fine sediments in the lower parts. The anomalies follow this pattern of scars and are higher, precisely in these points mainly because of the exposed rock in these places. Thus, the radionuclide mobility in this region is not only triggered by mass movements, but can also be related to factors such as rainfall and the drainage system. 


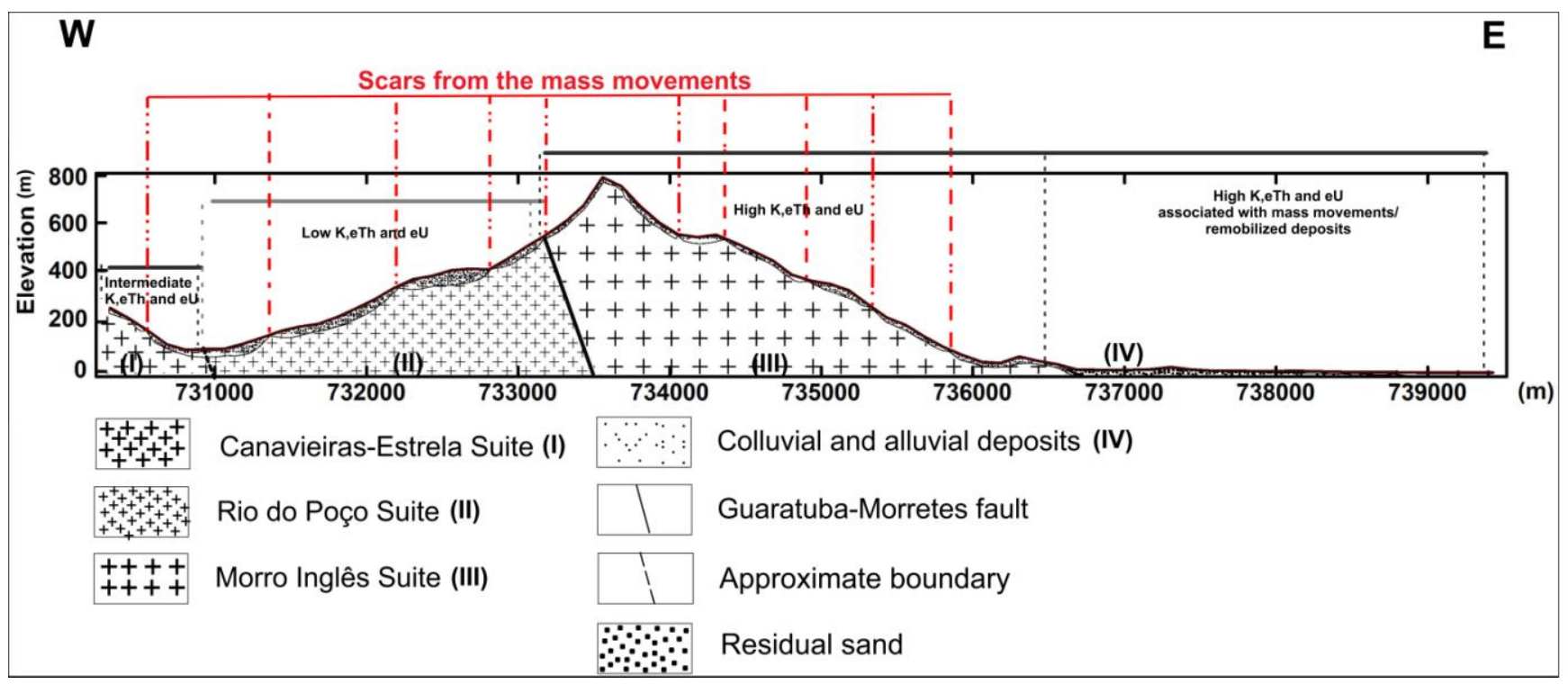

Figure 6 - Schematic geological profile $X-X$ ' of the northern portion of Serra da Prata ridge indicating the behavior of radionuclides

a)

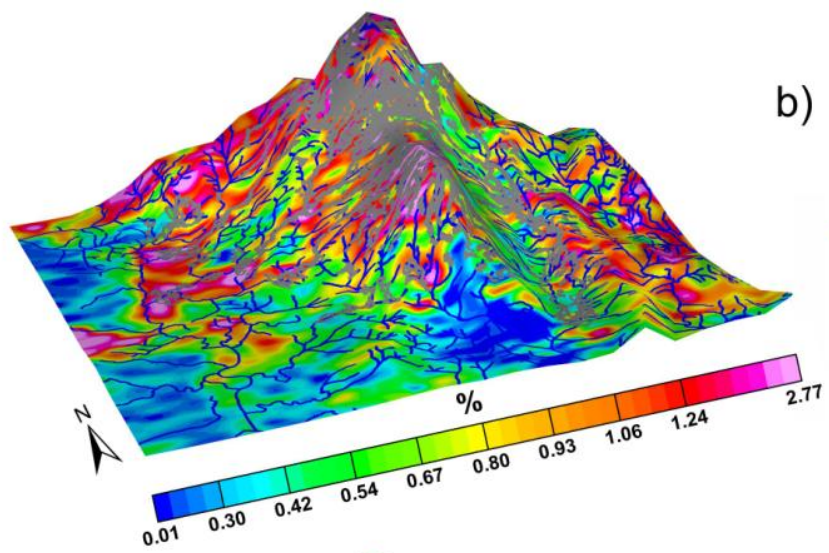

c)

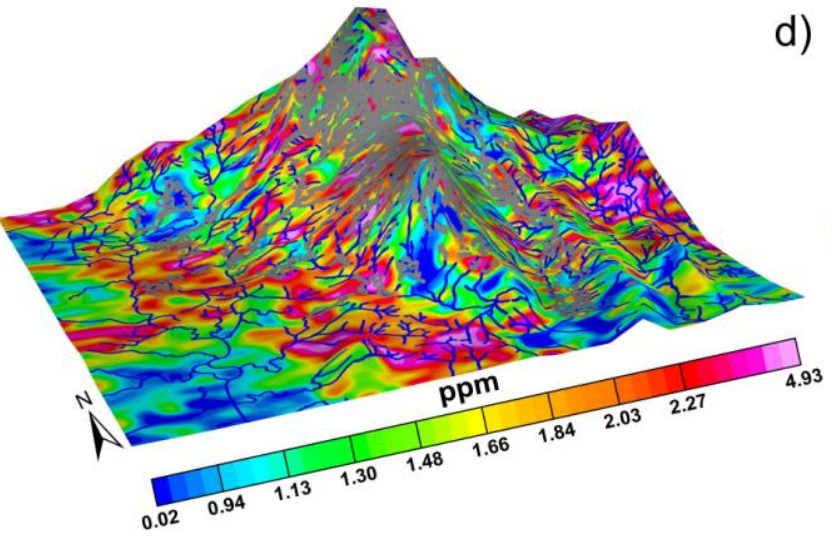

b)

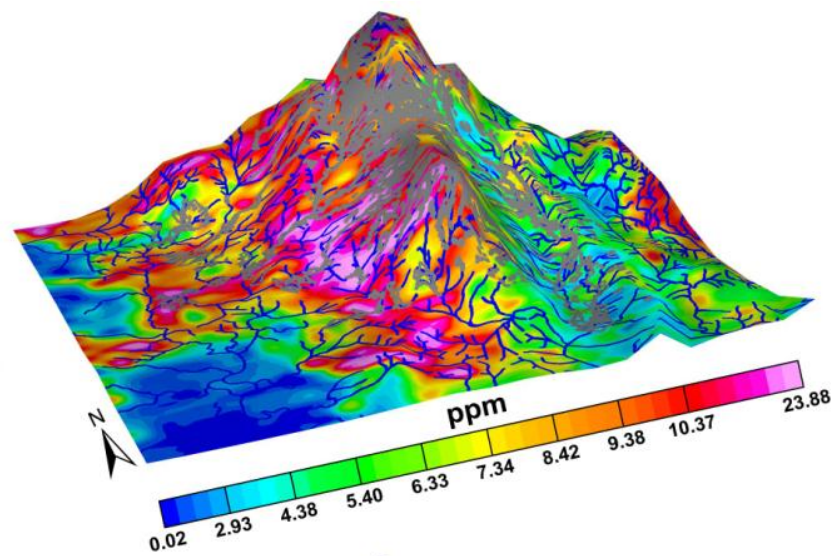

d)

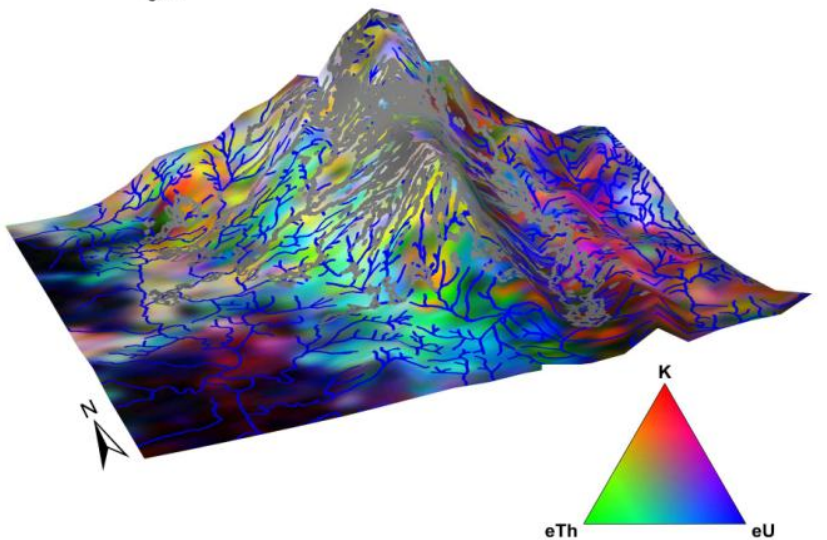

Figure 7-3D (a) K, (b) eTh, (c) eU and ternary maps of the northern portion of the Serra da Prata ridge, with the scars in gray 


\section{Conclusion}

Through the investigation of radionuclides mobility was possible to relate the $\mathrm{K}$, eTh and $\mathrm{eU}$ with mass movements. The scars associated with the landslides and mudslides produces high gamma-ray spectrometric anomalies due to the remobilization of coverage and the fresh rock exposure. In this way, the gamma-ray spectrometric method could be used to contribute with the research of mass movements associated with geomorphological and geotechnical studies.

\section{Ackonowledgments}

We are grateful to the Companhia de Pesquisa de Recursos Minerais (CPRM, Geological Survey of Brazil) who allowed us the use and publication of airborne geophysical data in the region of Paranaguá Terrane. J.D. Weihermann is grateful to Coordination for the Improvement of Higher Education Personnel (CAPES) for the scholarship. F.J.F. Ferreira was supported in this research by a fellowship from National Council for Scientific and Technological Development (CNPq) (contract 306978/2015-6).

\section{References}

Cury L. F., 2009. Geologia do Terreno Paranaguá. Tese de Doutorado, Instituto de Geociências, Universidade de São Paulo, São Paulo, 202p. In Portuguese.

Dickson, B. L., Scott, K. M.,1997. Interpretation of aerial gamma-ray surveys - adding the geochemical factors. AGSO Journal of Australia Geology and Geophysics, vol. 17( 2): $187-200$

Fiori, A.P., 1995. Estudo da estabilidade de vertentes da área de Guaraqueçaba, Paraná. Boletim Paranaense de Geociências,v. 43, p. 25-40. In Portuguese.

Gunn P.J., 1997. Quantitative methods for interpreting aeromagnetic data: a subjective review. AGSO Journal of Australian Geology \& Geophysics. 17(2): 105-113.

IAEA, 2003. Guidelines for radioelement mapping using gamma Ray spectrometry data. Viena: International Atomic Energy Agency (Technical Report Serie, ํㅡ1363), p. 173.

Minty, B.R.S., 1997. Fundamentals of airborne gammaray spectrometry. AGSO Journal of Australian Geology and Geophysics, 17 (2): 39-50.

Silveira, C.T., Fiori, A.P., Ferreira, A.M., Góis, J.R., Mio, G.; Silveira, R.M.P., Massulini, N.E.B., Leonardi, T.M.H., 2013. Emprego de atributos topográficos no mapeamento da suscetibilidade a processos geoambientais na bacia do rio Jacareí/Paraná. Sociedade \& Natureza (UFU. Online), v. 24: 623-639. In Portuguese.

Silveira, C.T., Fiori, A.P., Schilipack, P., Dias, S.M., 2014. Mapeamento preliminar da suscetibilidade natural a movimentos de massa da Serra do Mar Paranaense apoiado na análise digital do relevo. Revista Brasileira de Geomorfologia, vol.15(1): 3-22. In Portuguese.
Weihermann, J.D. 2016. Integração geofísico-geológica do Terreno Paranaguá, Sul do Brasil. Dissertação de Mestrado, Departamento de Geologia, Universidade Federal do Paraná, Curitiba, 101p. In Portuguese.

Wilford, J.R., Bierwirth, P.N., Craig, M.A., 1997. Application of airborne gamma-ray spectrometry in soil/regolith mapping and applied geomorphology. AGSO Journal of Australian Geology \& Geophysics, 17(2): 201216.

Wilford J., 2002. Airborne gamma-ray spectrometry. In: PAPPE. ed. Geophysical and remote sensing methods for regolith exploration. 